\title{
Effect of Casting Atmosphere on the Shear Bond Strength of a Ceramic to Ni-Cr and Ni-Cr-Be Alloys
}

\author{
Valéria Oliveira PAGNANO \\ Marina de Campos ESQUIVEL \\ Mônica Barbosa LEAL \\ Daniela Nair Borges FELIPUCCI \\ Osvaldo Luiz BEZZON \\ Department of Dental Materials and Prosthodontics, Ribeirão Preto Dental School, \\ University of São Paulo, Ribeirão Preto, SP, Brazil
}

\begin{abstract}
The success of metal-ceramic restorations depends on an optimal bond between metal and ceramic. This study evaluated the effect of 3 casting atmospheres on the metal-ceramic bond strength (MCBS) of $2 \mathrm{Ni}$-Cr alloys, with beryllium (Fit Cast V) and without beryllium (Fit Cast SB). Sixty acrylic resin patterns ( $8 \mathrm{~mm}$ long and $5 \mathrm{~mm}$ diameter) were obtained using a fluorocarbon resin matrix. Wax was used to refine the surface of acrylic resin patterns that were invested and cast in an induction casting machine under normal, vacuum, and argon atmospheres at a temperature of $1340^{\circ} \mathrm{C}$. The castings were divested manually and airborne-particle abraded with $100-\mu \mathrm{m}$ aluminum-oxide. Ten castings were obtained for each group. The IPS Classic V ceramic was applied $(2 \mathrm{~mm}$ high and $5 \mathrm{~mm}$ diameter). The shear bond strength was tested in a mechanical testing machine with a crosshead speed of $2.0 \mathrm{~mm} / \mathrm{min}$. The MCBS data $(\mathrm{MPa})$ were subjected to 2 -way analysis of variance $(\alpha=0.05)$. There was no statistically significant difference $(p>0.05)$ between the alloys or among the casting atmospheres. Within the limitations of this study, it may be concluded that the presence of beryllium and the casting atmosphere did not interfere in the MCBS of the evaluated metal-ceramic combinations
\end{abstract}

Key Words: casting atmosphere, metal-ceramic bond strength, $\mathrm{Ni}-\mathrm{Cr}$ alloys.

\section{INTRODUCTION}

Metal-ceramic restorations have been used for several years because of their excellent mechanic and biologic properties. The increase of gold price in the 1970 s resulted in the development of alternative metallic systems (1). Base metal alloys were developed with nickel, chromium and cobalt, and semi-noble alloys, which include Ag-Pd alloys and all alloys with $10 \%$ to $75 \%$ of gold in their formulation. Among these alternative alloys, $\mathrm{Ni}-\mathrm{Cr}$ alloys are the most used for fabrication of metal-ceramic crowns. These alloys present high rigidity and hardness, in addition to low cost.

Although base metal alloys have good mechanical properties, most of alternative alloys have disadvantages, such as biologic hazards, higher melting temperatures, need for more critical handling and care with the melting technique, and are more difficult to finish when compared to noble alloys (2-4). The presence of beryllium $(\mathrm{Be})$ in some compositions may determine the need of handling control because of its carcinogenic potential (5). On the other hand, Be reduces the melting point and increases the castability of the metal alloy $(2,5)$, in addition to promoting the formation of true oxide bars that extend into the inner part of eutectic Ni-Be phase or the dendrites where $\mathrm{Be}$ is maintained in solid solution, increasing the metal-ceramic bond strength (MCBS) (3).

For clinical success of metal-ceramic restorations, the development of an optimal bond between ceramic and metal substructure is essential (1,5-7). The chemical compatibility between metal and ceramic allows the restoration to resist thermal stress and mechanical forces, including firing temperature of the ceramic that does not cause distortion of the metal substructure and 
ceramic contraction that can be resisted by the metal (9).

Three mechanisms for metal-ceramic bond exist: mechanical interactions, chemical bond and van der Waals' forces. The mechanical retention depends on the superficial roughness and contributes for the increase of the area of reactions, promoting higher wetting of ceramic to the metal (10). In spite of this, the chemical bond represents the main factor of adhesion in the metal-ceramic systems (11) and it is directly related to the formation of an adherent oxide layer on metal surface $(5,12)$. The composition and thickness of this layer can be determinant for the success of the metal-ceramic bond and they depend on the technique and the materials used in the system. In the Ni-Cr alloys the chromium is responsible for the formation of a superficial layer of extremely adherent oxide to the metallic substratum, which provides the passivity and the resistance to the corrosion of this metallic alloy (12).

In spite of several tests designed and selected by researchers to evaluate MCBS, most studies have proposed the use of 3 or 4-point bending and shear bond strength tests (1). Two factors have been noticed: the inherent stress concentration at the final site of porcelain and the presence of residual thermal stress in the metal-ceramic specimen because of mismatch between 2 thermal contraction coefficients $(8,12)$. Some authors state that there is no methodology capable of measuring shear forces along the metal-ceramic interface $(1,5,12)$.

The good results of metal-ceramic restorations depend not only on the characteristics of the metal and ceramic, but also on the bond strength between both, beyond the processing technique control (13). The casting in the presence of oxygen may cause oxidation of metal elements with substantial reactions power and the manufacturers do not give no information concerning casting atmosphere. The use of casting machines that enables closing the control of casting conditions may represent a significant contribution to improving the quality of dental restorations with metal base alloys.

Considering that Ni-Cr alloys are still used in metal-ceramic restorations because of their low cost and desirable mechanical properties, the aim of this study was to evaluate the effect of different casting atmospheres (normal, vacuum, and argon) on the MCBS of $2 \mathrm{Ni}-\mathrm{Cr}$ alloys, with and without Be. The null hypothesis tested was that the MCBS of the Ni-Cr alloys is not different at 3 casting atmospheres.

\section{MATERIAL AND METHODS}

The metal-ceramic shear bond strength of 2 Ni-Cr base metal alloys - one with Be (Fit Cast V; Talladium Inc., Valencia, PA, USA) and another without Be (Fit Cast SB; Talladium Inc) - were evaluated when cast at 3 casting atmospheres. A fluorocarbon resin (Teflon; Dupont, Wilmington, DE, USA) matrix consisting of 4 independent pieces (Figs. 1A and B) was used for specimen fabrication. The first part was a ring $(20 \mathrm{~mm}$ diameter and $30 \mathrm{~mm}$ high) with 5-mm-diameter hole in the center. The second part was a piston ( $4.9 \mathrm{~mm}$ diameter

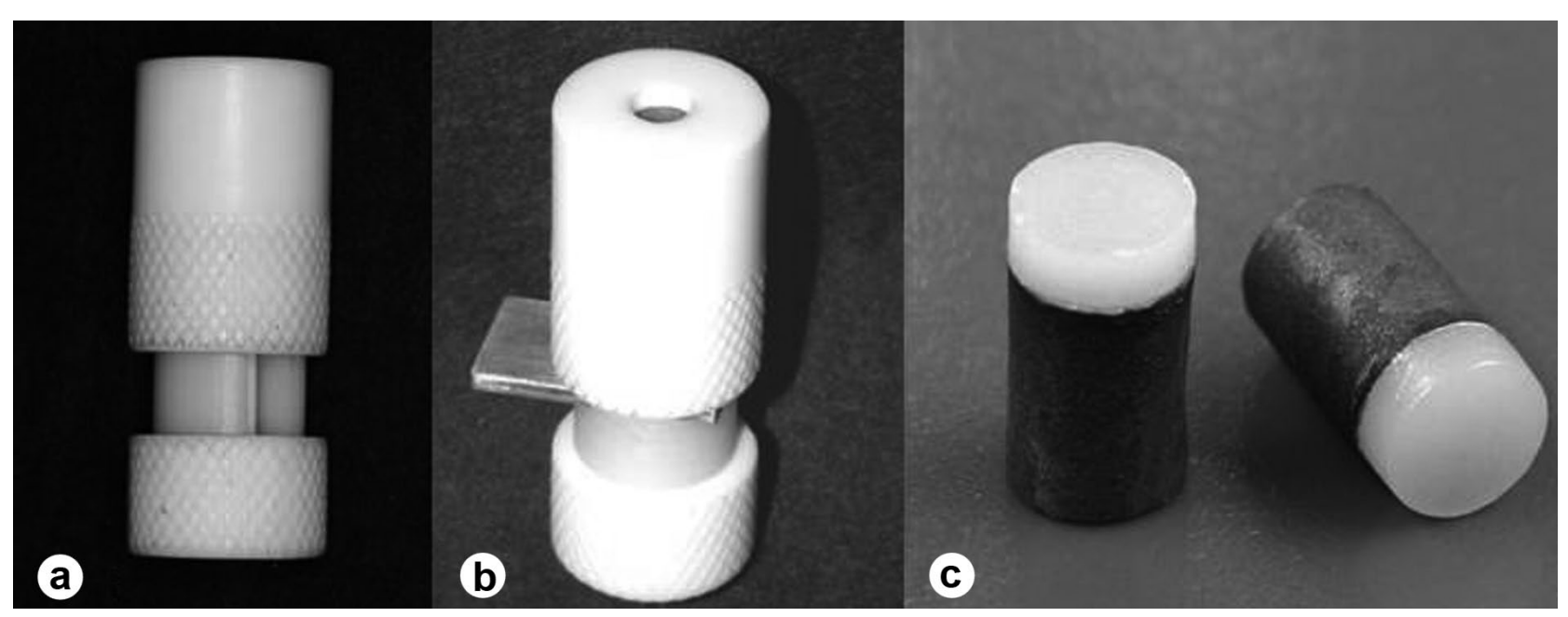

Figure 1. Specimen fabrication. A: Fluorocarbon resin matrix with $8 \mathrm{~mm}$ spacer positioned to obtain the resin-wax patterns. B: Matrix with 2-mm and 8-mm spacers positioned with metal cylinder placed for ceramic application process. C: Metal-ceramic specimen. 
and $30 \mathrm{~mm}$ high) with a base (30 $\mathrm{mm}$ diameter and 12 $\mathrm{mm}$ high), which was used to remove the specimens. The set of matrix components also included 2 spacers ( $8 \mathrm{~mm}$ and $2 \mathrm{~mm}$ high), which were used to standardize the casting pattern and ceramic layer thickness (Fig. 1A-C).

In order to form the casting patterns $(8 \mathrm{~mm}$ long and $5 \mathrm{~mm}$ diameter), the piston and the hollow cylinder were isolated with an acrylic resin separator (Reliance Dental Mfg Co, Worth, IL, USA). An autopolymerizing acrylic resin (Duralay; Reliance Dental Mfg Co) was poured into the matrix with the $8 \mathrm{~mm}$ spacer. After resin polymerization, inlay casting wax (GEO Classic transparent blue; Renfert GmbH, Hilzingen, Germany) was used to refine the acrylic resin pattern surface.

The cylinder-shaped wax/acrylic resin patterns were attached to sprues $(20 \mathrm{~mm}$ long and $3-\mathrm{mm}$ diameter, with a 6.5 -mm-diameter reservoir) with inlay casting wax (GEO Classic transparent blue; Renfert $\mathrm{GmbH}$ ) at 45-degree angle to the cylinder long axes. The wax/ acrylic resin patterns were invested in phosphate-bonded investment (Micro Fine 1700; Talladium Inc.) that was mixed at a spatulation speed of $425 \mathrm{rpm}$, under vacuum, for $40 \mathrm{~s}$ in a vacuum investor (Model A300; Polidental, São Paulo, SP, Brazil) using the mixing powder/liquid ratio recommended for the manufacturer $(90 \mathrm{~g} / 22 \mathrm{~mL})$. Rings were allowed to bench set for $20 \mathrm{~min}$. Each investment mold contained 2 patterns. The casting rings were placed in the furnace (Model Edgcon 5P; EDG Equipments, São Carlos, SP, Brazil) to burn out patterns and thermally expand the molds.

After removal from the furnace, the casting rings were positioned in an induction casting machine (Neutrodyn Easyti; Manfredi SpA, Torino, Italy), where the alloys were melted in a crucible under normal (n), vacuum (v) (580 mm Hg), and argon (a) atmospheres at a temperature of $1340^{\circ} \mathrm{C}$. When the alloy reached the pre-selected temperature, molten $\mathrm{Ni}-\mathrm{Cr}(\mathrm{SB})$ and $\mathrm{Ni}-\mathrm{Cr}-$ $\mathrm{Be}(\mathrm{V})$ alloys were cast into the molds with centrifugal force. Therefore, 60 castings were made and distributed to 6 groups $(\mathrm{n}=10)$ : $\mathrm{Vn}$ group - Ni-Cr-Be alloy casting under normal atmosphere; Vv group - Ni-Cr-Be alloy casting under vacuum; Va group - Ni-Cr-Be alloy casting under argon atmosphere; SBn group - Ni-Cr alloy casting under normal atmosphere; $\mathrm{SBv}$ group - Ni-Cr alloy casting under vacuum; and SBa group - Ni-Cr alloy casting under argon atmosphere.

After the rings cooled, the castings were divested manually and airborne-particle abraded (Microjet III; EDG Equipments, São Carlos, SP, Brazil) with 100$\mu \mathrm{m}$ aluminum-oxide under 2-bar pressure for $5 \mathrm{~s}$ to removal residual investment. The castings were then separated from their sprues. Before applying ceramic, the specimens were once again airborne-particle abraded with $100-\mu \mathrm{m}$ aluminum-oxide under 2-bar pressure for $5 \mathrm{~s}$ maintaining a $2.0-\mathrm{cm}$ distance and an approximate 45-degree angle. After airborne-particle abrasion, the metal specimens were ultrasonically cleaned (Ultrasonic Clearer Plus 3LDA; Odontobras, Ribeirão Preto, SP, Brazil) with isopropyl alcohol, with a 10-min time.

The IPS Classic V ceramic (IPS Classic V; Ivoclar Vivadent, Schaan, Liechtenstein) was used. The opaque ceramic paste was applied in 2 layers over the $5-\mathrm{mm}$ diameter surface of the metal cylinder. After the opaque ceramic firing cycle, each specimen was placed into the matrix with both $2-\mathrm{mm}$ and $8-\mathrm{mm}$ spacers to standard the dimensions of ceramic disk ( $2 \mathrm{~mm}$ high and $5 \mathrm{~mm}$ diameter) (Fig. 1B). The first layer of dentin ceramic was applied and the metal alloy/ceramic assemblies were carefully removed and fired in a furnace (Sollaris 50P; Futura Brasil, São Carlos, SP, Brazil). Thereafter, the second layer of dentin ceramic was applied and fired to compensate for ceramic shrinkage. The firing cycles were done following the ceramic manufacturer instructions. Therefore, the specimens consisted of 2 parts: a metal cylinder and a ceramic disk (Fig. 1C).

The evaluation of the MCBS was made by shear bond test. The metal-ceramic specimens were positioned into a stainless steel device with a central hole $(8 \mathrm{~mm}$ high and $5 \mathrm{~mm}$ diameter), leaving the ceramic layer visible outside the device, in such a way that the shear forces could be applied only at metal/ceramic interface. The specimens were subjected to testing in this apparatus mounted on a screw driven of the mechanical testing machine (DL2000; EMIC, São Jose dos Pinhais, PR, Brazil) with a $0.5-\mathrm{mm}$-thick bevel-shaped rod at a crosshead speed of $2 \mathrm{~mm} / \mathrm{min}$ (Fig. 2). The mean shear bond strength values were analyzed by 2-way analysis of variance and Tukey's test at 5\% significance level.

\section{RESULTS}

Ten repetitions were performed for each of the 6 groups and a total of 60 specimens were evaluated. Since the data had a non-normal distribution, ANOVA was performed after logarithmic transformation (normal 
distribution) of the original data. There was no statistically significant difference $(\mathrm{p}>0.05)$ between the alloys or among the casting atmospheres. The MCBS results and the type of bond failure are presented in Table 1.

\section{DISCUSSION}

The null hypothesis was accepted because there were no significant differences in the MCBS among all combinations of alloys and casting atmospheres.

$\mathrm{Ni}-\mathrm{Cr}$ alloys are alternatives to gold alloys because they have good mechanical properties, such as high hardness, low density and high tensile strength $(3,14)$. In addition, the low cost and easy manipulation of Ni-Cr alloys have made them widely used in the fabrication of metal-ceramic restorations (14), which combine the resistance of the metal substructure with esthetic properties of the ceramic $(7,15,16)$.

Considering the studied alloys, the findings of the present investigation (Table 1) do not agree with those of previous studies $(3,6,14)$, which observed higher MCBS for Be-containing alloys when compared to Befree alloys. It is possible that the use of the induction casting technique, in which there was always the alloy protection may have contributed to the homogeneity in the results observed for different combinations. In addition, in this experiment, any pre-heating treatment of the alloys was not performed aiming at to minimize the effect of the chemical interaction among the evaluated materials (17). According to a previous study (14), the presence of $\mathrm{Al}\left(\mathrm{as}_{2} \mathrm{O}_{3}\right)$ and $\mathrm{Be}(\mathrm{as} \mathrm{BeO})$ on the oxide

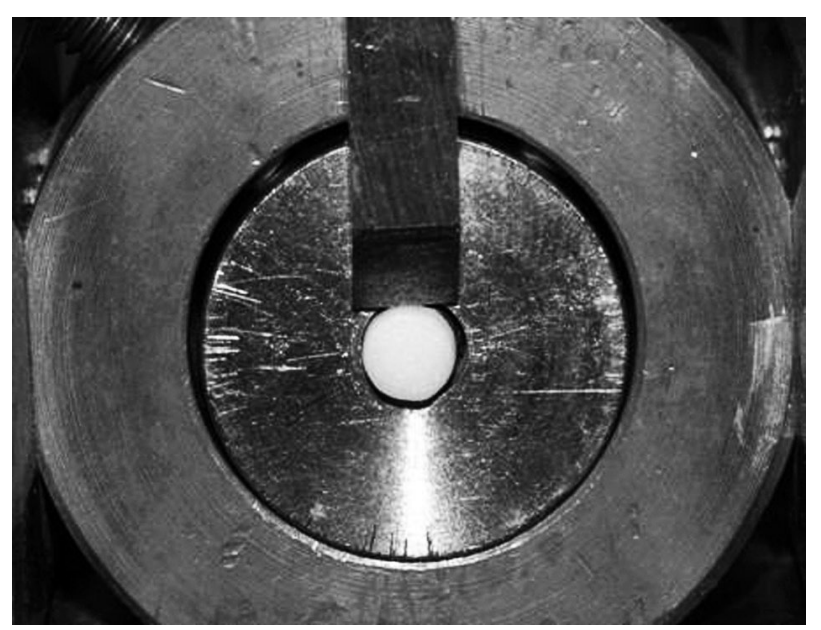

Figure 2. Shear bond strength testing, showing force being applied at the metal-ceramic interface. layer of Ni-Cr alloy specimens subjected to pre-heating resulted in a better metal-ceramic bonding behavior. Therefore, it is possible that for Fit Cast V alloy, which contains $\mathrm{Al}$ and $\mathrm{Be}$ in its formulation, the MCBS values could be improved if the pre-heating treatment was used. Notwithstanding, considering the results of the present study, which showed no difference between the alloys, the biologic hazards of the Be may be avoided by using the Ni-Cr alloy without this cytotoxic element.

The present study showed that Ni-Cr and Ni-CrBe alloys cast at normal, vacuum, and argon casting atmospheres resulted in similar MCBS mean values (Table 1). According to the literature, the vacuum-pressure casting machine creates a reduced atmosphere that prevents an oxidation of the alloy components (18). In this study, it is possible that any eventual difference generated by the foundry environment could have been eliminated by the standard superficial treatment of the alloy.

The incorrect use of a direct gas-oxygen flame may affect the properties of Ni-Cr alloys (19), despite its ideal formulation and mold temperature, due to the possibility of over- or under-melting temperature and use of the oxidizing zone of the flame during casting. In the present study, specimens were not cast by gas-oxygen flame technique. Nevertheless, it is possible that the use of these methods might have resulted in lower MCBS values when compared to other groups, since the use of casting machines that enables closing the control of casting conditions may represent a significant contribution to improving the quality of dental restorations with base metal alloys (19). However, to the best of our knowledge, there were no studies that evaluated the effect of casting atmosphere on the MCBS of the Ni-Cr alloys.

In view to the limitations of the methodology employed in the present experiment, it was difficult

Table 1. Shear bond strength mean values (MPa) and standard deviations (SD) and failure modes $(\mathrm{n}=10)$.

\begin{tabular}{ccccc}
\hline Groups & Mean (SD) & $\begin{array}{c}\text { Adhesive } \\
\text { failure }\end{array}$ & $\begin{array}{c}\text { Cohesive } \\
\text { failure }\end{array}$ & $\begin{array}{c}\text { Mixed } \\
\text { failure }\end{array}$ \\
\hline V-n & $62.69(7.6)$ & 0 & 0 & 10 \\
V-v & $57.09(17.9)$ & 0 & 0 & 10 \\
V-a & $54.62(16.5)$ & 0 & 0 & 10 \\
SB-n & $55.08(13.2)$ & 0 & 0 & 10 \\
SB-v & $55.84(16.5)$ & 0 & 0 & 10 \\
SB-a & $63.47(10.4)$ & 0 & 0 & 10 \\
\hline
\end{tabular}


to compare the obtained results to those of previous investigations, since different designs for shear bond tests have been used to assess MCBS. Although various types of tests have been described in the literature to evaluate metal-ceramic bond strength (20), there is no methodology capable of purely measuring shear forces along the metal/ceramic interface (12) because specimens contain residual thermal stresses at the interface due to a mismatch of the coefficient of linear thermal expansion (CTE) of the ceramic and metal.

The visual analysis of failure modes revealed that the fractures seemed to occur along the porcelain-metal interface, with some porcelain remnants on the metal surface. All failures were characterized as adhesive/ cohesive failures (Table 1). According to the literature $(8,15)$, adhesive failure within the porcelain is the most desirable bond failure mode, indicating a strong bond between the oxide layer and both the metal and ceramic.

Due to the high complexity of metal-ceramic bonding, further studies are needed to investigate the influence of controlling other factors that were not considered in this experiment to improve the MCBS of alternative alloys. Within the limitations of this study, it may be concluded that the Ni-Cr and Ni-Cr-Be alloys had similar MCBS and there was no significant difference in the MCBS among the casting atmospheres (normal, vacuum, and argon).

\section{RESUMO}

O sucesso das restaurações metalocerâmicas depende da ótima união entre metal e cerâmica. Este estudo avaliou o efeito de 3 atmosferas de fundição na resistência de união metalocerâmica (RUMC) de 2 ligas de $\mathrm{Ni}-\mathrm{Cr}$, com berílio (Fit Cast V) e sem berílio (Fit Cast SB). Sessenta padrões de resina acrílica (comprimento de $8 \mathrm{~mm}$ e diâmetro de $5 \mathrm{~mm}$ ) foram obtidos usando uma matriz de teflon. Foi utilizada cera para refinar a superfície dos padrões de resina acrílica que foram incluídos e fundidos em máquina de fundição por indução nas seguintes atmosferas de fundição: normal, vácuo e argônio, à temperatura de $1340^{\circ} \mathrm{C}$. As fundições foram removidas e usinadas com partículas de óxido de alumínio de $100 \mu \mathrm{m}$, sendo 10 fundições por grupo. Foi aplicada a cerâmica IPS Clássico V ( $2 \mathrm{~mm}$ de altura e diâmetro de 5 $\mathrm{mm})$. O ensaio de cisalhamento foi realizado em máquina de ensaios mecânicos com velocidade de 2,0 $\mathrm{mm} / \mathrm{min}$. Os dados de RUMC $(\mathrm{MPa})$ foram analisados por meio da análise de variância $(\alpha=0,05)$. Não houve diferença significante $(p>0,05)$ entre as ligas e entre as atmosferas de fundição. Dentro das limitações deste estudo, pode-se concluir que a presença do berílio e a atmosfera de fundição não interferiram na RUMC das combinações metalocerâmicas avaliadas.

\section{ACKNOWLEDGEMENTS}

This study was supported by grants (\#04/14390-6 and \#04/14391-
2) from The State of São Paulo Research Foundation, Brazil.

\section{REFERENCES}

1. Melo RM, Travassos AC, Neisser MP. Shear bond strengths of a ceramic system to alternative metal alloys. J Prosthet Dent 2005;93:64-69.

2. Bezzon OL, Mattos MGC, Ribeiro RF, Rollo JMDA. Effect of beryllium on the castability and resistance of ceramometal bonding in nickel-chromium alloys. J Prosthet Dent 1998;80:570-574.

3. Bezzon OL, Ribeiro RF, Rollo JMDA, Crosara S. Castability and resistance of ceramometal bonding in $\mathrm{Ni}-\mathrm{Cr}$ and $\mathrm{Ni}-\mathrm{Cr}-\mathrm{Be}$ alloys. J Prosthet Dent 2001;85:299-304.

4. Prado RA, Panzeri H, Fernandes Neto AJ, Neves FD, Silva MR, Mendonça G. Shear bond strength of dental porcelains to nickelchromium alloys. Braz Dent J 2005;16:202-206.

5. Baran GR. Auger chemical analysis of oxides on Ni-Cr Alloys. J Dent Res 1984;63:76-80.

6. Mackert JR Jr, Butts MB, Fairhurst CW. The effect of the leucite transformation on dental porcelain expansion. Dent Mater 1986;2:32-36.

7. Joias RM, Tango RN, Araujo JEJ, Araujo MAJ, Saavedra GSFA, Paes-Junior TJA, et al.. Shear bond strength of a ceramic to Co-Cr alloys. J Prosthet Dent 2008;99:54-59.

8. Akova T, Ucar Y, Tukay A, Balkaya MC, Brantley WA. Comparison of the bond strength of laser-sintered and cast base metal dental alloys to porcelain. Dent Mater 2008;10:1400-1404.

9. Ylmaz H, Dinçer C. Comparison of the bond compatibility of titanium and an NiCr alloy to dental porcelain. J Dent 1999;27:215-222.

10. Fédération Dentaire Internationale. Alternative casting alloys for fixed prosthodontics - Technical report n.34, Int Dent J 1990;40:54-55.

11. Hegedus C, Daroczi L, Kokenyesi, Beke DL. Comparative microstructural study of the diffusion zone between $\mathrm{Ni}-\mathrm{Cr}$ alloy and different dental ceramics. J Dent Res 2002;81:334-337.

12. Anusavice KJ, Dehoff PH, Fairhurst CW. Comparative evaluation of ceramic-metal bond tests using finite element stress analysis. J Dent Res 1980;59:608-613.

13. Dent RJ, Preston JD, Moffa JP, Caputo A. Effect of oxidation on ceramometal bond strength. J Prosthet Dent 1982;47:59-62.

14. Huang HH, Lin MC, Lee TH, Yang HW, Chen FL, Wu SC, et al.. Effect of chemical composition of Ni-Cr dental casting alloys on the bonding characterization between porcelain and metal. J Oral Rehabil 2005;32:206-212.

15. Papazoglou E, Brantley WA, Carr AB, Johnston WM, Carr AB. Effects of dental laboratory processing variables and in vitro testing medium on the porcelain adherence of high-palladium casting alloys. J Prosthet Dent 1998;79:514-519.

16. Anusavice KJ, Shen C, Hashinger D, Twiggs SW. Interactive effect of stress and temperature on creep of PFM alloys. J Dent Res 1985;64:1094-1099.

17. Lopes SC, Pagnano VO, Rollo JMDA, Leal MB, Bezzon OL. Correlation between metal-ceramic bond strength and coefficient of linear thermal expansion difference. J Appl Oral Sci 2009;17:122-128.

18. Engstrom G, Fredriksson H, Wictorim L. Absorption of gas in dental gold alloys during melting. J Oral Rehabil 1982;9:35-44.

19. Bezzon OL, Barros C, Pagnano VO, Soriani NC. Effect of casting temperature and atmosphere on castability of $\mathrm{Ni}-\mathrm{Cr}$ alloys: a comparative study with direct flame casting method. Materials Research 2006;9:245-249.

20. Hammad IA, Talic YF. Designs of bond strength tests for metal-ceramic complexes: review of the literature. J Prosthet Dent 1996;75:602-608. 